\title{
Sustainable Supply Chain Management at Clif Bar
}

\author{
Kwesi Atta Sakyi \\ B.A. (Hons.) Ghana MPA (summa cum laude) (Head-Research) \\ ZCAS University Dedan Kimathi Road, Lusaka, Zambia
}

\begin{abstract}
This paper has the objective of discussing the concept of sustainability by examining the practice in a case study of Clif Bar, a US-based company that deals in manufacturing nutritional foods for sports people, and whose model is outsourcing their core activities from upstream through mid-stream to downstream to small-scale farmers, cooperatives, and suppliers in the supply chain. The methodology adopted is that of review of secondary sources for analysis and insight. The concepts of sustainability and corporate social responsibility are discussed theoretically and practically in relationship to Clif Bar. The paper concludes that undertaking sustainability measures and corporate social responsibility may be costly in the short-run but highly beneficial to all in the long-run. It requires a multidisciplinary approach with a team comprising employees from diversified backgrounds.
\end{abstract}

Key Words: supply chain, sustainability, integration, outsourcing, green practices, organic food

\section{INTRODUCTION}

Clif Bar was set up by Gary Erickson after his biking experience in 1990 when he consumed a nutrition energy bar and he came up with the idea of producing a better alternative bar for sports people that he called his company Clif Bar \& Company (Krajewski et al., 2015:617).

He decided to include whole grains, nuts and fruits which were sourced locally from organic farmers, ranchers, and cooperative society out-growers and sharecroppers in a backward integration (Krajewski et al., 2015:617). His final product was distributed by cyclists and small scale retailers who were spread all over the US. According to Krajewski et al. (2015:617), more than 70 per cent of his products were certified to be from organic sourcing. Clif Bar is based in Berkeley, California and it outsources the ingredients and inputs from local suppliers and has distributers such as Whole Foods and Trader Joe's.

Sustainability refers to ability to meet current needs of people without jeopardising the needs of future generations (Krajewski et al., 2015) Sustainability has three main aspects pertaining to the 3Rs of Reduce, Reuse, and Recycle (ConserveEnergyFuture, 2019) and also the Triple Bottom Line (3Ps) of Elkington (1992) of paying attention to the needs namely of People, Planet, and Profit, or alternatively according to Krajewski et al.(2015) having Social, Environmental, and Financial responsibilities to all stakeholders along the supply chain. Clif Bar shows ethical and moral responsibility to its customers by making sure they eat healthy foods and have value for money as most are well-educated, health conscious, and sophisticated in outlook. Clif Bar wants to forge lasting bonds with its clientele by paying attention to their needs and satisfying them to the maximum, hence going organic, green and being environmentally-friendly.

It also treats its suppliers with respect and dignity so that they can have long-lasting and sustainable relationship. Suppliers are screened to select the best so that they supply quality 
ingredients which are in line with specifications given and that these suppliers use energyefficient sources of power, and that they uphold high labour standards in the way they treat their workers. Suppliers and other stakeholders in the supply chain are always informed in advance of new developments by using user interfaces in the communication networks in the various highly-integrated supply chains. By practicing Corporate Social Responsibility (CSR), Clif Bar endears itself to the community, the end-users and it guarantees support to them by being caring, philanthropic, charitable, and humane or being a good corporate citizen. For example, Body Shop Company ensures that its products are ethically sourced by respecting animal rights and culture of people. MacDonald made potato chips with beef flavour which offended Hindus in India. They had to apologize and withdraw the product which created huge reputation loss for them and also high costs of reverse logistics in recycling, re-routing, reworking and perhaps destroying some packets.

Donnelly Company (Krajewski et al., 2015) ensures the minimum use of packaging materials for products to reduce material wastage and to be green. To be sustainable, Clif Bar listens to the concerns of Interest and Pressure groups in order to comply. Carroll came up with her PEELS model (tutor2u.org ) to help firms become sustainable by considering Philanthropic, Ethical, Environmental/ Economic, Legal, and Social concerns and responsibilities.

\section{DISCUSSION}

\section{Risks in Supply Chain Outsourcing faced by Clif Bar Company}

Clif Bar does not buy Genetically-Modified Organisms (GMOs) from farmers and also in line with its ethical stance of being environmentally -friendly, it does not encourage its farmers to use herbicides and pesticides, which implies higher costs for suppliers and lower yields for them, thereby giving advantage to competitors (Krajewski et al., 2015)

Clif Bar has risk of having ingredients with short life cycles and short shelf lives, necessitating that they research to preserve some of these ingredients. Consumer tastes also change rapidly. Therefore there is risk of obsolescence of stock. To reduce this risk, Clif Bar should always be researching to create new products to replace old ones and also discover new markets where old products can be sold (cf. Ansoff Product/Market Growth Matrix)

This has financial risk implications for supplies as more research has to be done on increasing yields for organic foods. Apart from this financial risk, there are financial risks in outsourcing which can be dealt with by hedging and futures contracts so that adverse factors in the sourcing and financial markets are contained by being proactive. A buffer scheme can be arranged to meet certain spikes and bursts in demand. This is despite practising Lean, JIT, Cell, and TQM systems of production.

We also have Operational, Security, and Physical risks in outsourcing (Krajewski et al.,2015) Operational risks arise where upstream and downstream demand forecasts do not synchronize or are not in equilibrium, leading to either under- or over-stocking with their accompanying costs. In a developing country with poor infrastructure, Clif Bar can face physical challenges and delays in transporting goods to distribution centres and markets. Physical risks can be due to Acts of God such as storms, floods, pests, earthquakes, drought and bad weather. Humanmade obstacles include civil wars, poor planning, political instability, human disasters such as fire outbreaks, theft, accidents due to negligence, and fluctuations in tastes.

These are uncontrollable and Clif Bar has to adapt to them by being proactive with some response mechanisms as well as recovery mechanisms. Clif Bar should always have some slack capacity for contingencies. Security risks come in the form of risk to patents and intellectual 
property, risk to communication platforms such as hacking, virus attacks, spyware and malware, and loss of data due to power outages. To mitigate these risks, Clif Bar should have flexible systems, diversified activities and power sources such as using reliable, green, efficient, and renewable energy such as wind, solar, tidal, biofuels, and geothermal energy (ConserveEnergyFuture, 2019) Clif Bar can also use storage of data in the Cloud to avoid data loss.

The greatest risk to Clif Bar is its reliance on outsourced producers and distributers which situation can compromise quality of goods, quality of delivery on time, and costs to it as it has no options or capacity of producing its own products. This interdependence shows great vulnerability to preserving patent rights and also being autonomous in decision-making.

It has no freedom to make cost decisions because its costs are not internally-driven but externally-determined.

\section{Issues of Sustainability in Global Operations}

In operating outside the boundaries of their home country, Clif Bar can observe the 17 UN Sustainable Development Goals (SDGs) particularly the highlighted ones below:

- Donate what you do not use (Eradicate poverty)

- Avoid throwing away food (Zero hunger)

- Vaccinate families to protect them (Uphold well-being of staff and customers)

- Quality Education (Pay attention to staff development and training needs)

- Gender Equality

- Clean Water and Sanitation

- Affordable and Clean Energy

- Decent Work and Economic Growth.

- Industry Innovation and Infrastructure

- Reduced Inequalities

- Sustainable Cities and Communities

- Responsible Production and Consumption

- Climate Action

- Life below water

- Life on land

- Peace, Justice and Strong Institutions

- Partnerships (UN, 2018)

\section{RECOMMENDATIONS}

In foreign operations, Clif Bar will have to observe local laws and mores by respecting people's cultures and laws such as not using plastic containers, best ways to dispose packages and containers, and avoiding controversial activities such as being involved in blood or conflict diamonds, taking steps to guard their intellectual property from being pirated or counterfeited, overcoming winding bureaucratic hurdles by forging local transparent networks which are not based on bribery and corruption, avoiding sourcing inferior materials from some dubious and fake local suppliers, avoiding making the mistake of engaging suppliers with low capacity and capability who will in turn subcontract work to incompetent suppliers, causing delays in deliveries, and inferior goods to be supplied to clients leading to rejects, high reverse logistic costs, loss of custom, trust, and reputation.

Clif Bar should select its foreign partners carefully to ensure that they do not engage in slave labour, exploitation of women and children, and that these partners observe norms of 
transparency, equity, non-discrimination, are equal opportunity employers, comply with gender mainstreaming policies to avoid glass ceilings and glass walls, sticky floors and labour disputes where there is no industrial democracy for workers to exercise voice, capture and exit. Clif Bar Vice President, Greg Ginsburg wants their core values embedded in their entire supply chains, both internally and externally. This requires Clif Bar to train their suppliers and partners to bring them at par with their core values.

Farmers and distributers can be given credit facilities, incentives and bonuses or share options to empower them as part of CSR. Clif Bar should have good Corporate Governance in order to comply with the law such as Sarbanes-Oxley Act 2002 for listed companies.

This requires fiduciary care, following due process, transparency, probity and accountability. Suppliers should be paid on time and credit facilities can be extended to small scale farmers. Farmers who add value to Clif Bar's activities can be singled out and rewarded. The same should be done for employees for long time loyalty and performance. The work environments should be ergonomic, safe and free from unnecessary accidents.

\section{CONCLUSION}

Supply chain management requires a holistic approach which incorporates many disciplines such as Finance, Human Resource Management, Project Management, Purchasing and Supply, Logistics, Transportation Economics, Production Management, Organisational Behaviour, Industrial Relations, International Trade, Environmental Management, Energy Economics, and many others. This paper looked at Clif Bar, a nutrition and energy Production Company in California, USA. The Company incorporates many good practices embedded in their operations along their entire supply chain as espoused by their VP, Gary Ginsburg, and in line with the 17 UN SDG goals. They also incorporate best practices such as CSR, PEELS, 3Rs, 3Ps, PPP, among others.

\section{References}

3M (2019) New Annual Sustainability Report [Online] Retrieved from

https://www.3m.com/3M/en US/sustainability-us/

3M (2019) Plant Locations [Online] Retrieved from https:www.3m.com/3M/en_US/plant-locations-us/

Burus, P. (2013) Corporate Entrepreneurship-Innovation and Strategy in Large Organizations New York, N.Y.: Palgrave Macmillan pp.90-93

ConserveEnergyFuture (The) Reduce, Reuse, Recycle Waste Hierarchy [Online] Retrieved from https://www.conserve-energy-future.com/

Cousins, P., Lamming, R., Lawson, B. \& Squire, B. (2008) Strategic Supply Management- Principles, Theories and Practice Harlow, Essex: Pearson Education Limited pp. 198-206

Gadde, L.E., Hakansson, H \& Parsson, G. (2010) Supply Network Strategies New York, N.Y.: John Wiley Kaplan R.S., \& Norton, D.P. (1992) Balanced Scorecard Harvard Business Review

Harmon, P. (2007) Business Process Change (2nd ed.) New York, N.Y.: Morgan Kaupfmann

Kaplan R.S., \& Norton, D.P. (1992) Balanced Scorecard Harvard Business Review

Krewjeski, L. J., Malhotra, M.K., \& Ritzman, L.P. (2015) Operations Management: Processes and Supply Chains (11'th ed.) Pearson Education Limited

Lindorff, M., Jonson, E.P., McGuire, L. (2012) Strategic Corporate Social Responsibility in Controversial Industry Sectors: The Value of Harm Minimization[Online] Retrieved from DOI: 10.1007/s10551-012-1493-1

https://www.researchgate.net/publication/257541901_Strategic Corporate Social Responsibility in Controvers ial Industry Sectors The Social Value of Harm Minimisation

Lyson, K. \& Farrington, B. (2009) Purchasing and Supply Chain Management Harlow, Essex: FT Prentice Hall 
Mangan, J., Lalwani, C., Butcher, T. \& Javadpour, R. (2012) Global Logistics and Supply Chain Management New York, N.Y.: John Wiley

Porter, M.E. \& Kramer, M.R. (2006) Strategy and Society-The Link between Competitive Advantage and Corporate Social Responsibility [Online] Retrieved from Harvard Business Review

https://www.sharedvalue.org/sites/default/files/resource-files/Strategy and Society.pdf

Saunders, M. (1997) Strategic Purchasing and Supply Chain Management

Slack, N., Chambers, S. \& Johnston, R. (2010) Operations Management Harlow, Essex: Pearson Education Limited

Tutor2u Carroll's Pyramid [Online] Retrieved from

https://www.tutor2u.net/business/reference/carrolls-csr-pyramid

UN (2018) About the Sustainable Development Goals [Online] Retrieved from

https://www.un.org/sustainabledevelopment/sustainable-development-goals/ 